\title{
Recurrence of acute duodenal ulcer
}

RJ Bailey, IG Morrison-Cleator, A Farley, A Archambault, M Oravec, RS Davies, LR Sutherland, M Grace, AND THE NizATIDINE MUlticENTRE DUODENAL UlCER STUdy GROUP

RJ BAILEY, IG MORRISON-CleAtor, A FARLEY, et al, AND THE NiZATID. INE MULTICENTRE DUODENAL ULCER STUDY GROUP. Recurrence of acute duodenal ulcer. Can J Gastroenterol 1994;8(1):21-26. Nizatidine, $300 \mathrm{mg}$ once nightly, was compared with cimetidine, $800 \mathrm{mg}$ once nightly, for treatment of 212 adult out-patients with acute duodenal ulcers in an eight-week randomized, double-blind, multicentre trial. Patients were endoscoped at weeks 2, 4 and 8 , regardless of ulcer healing status. No significant differences in ulcer healing rates between treatment groups were seen at weeks 2 and 4 , but at week 8 , nizatidine had a significantly higher ulcer healing rate $(\mathrm{P}=0.036)$ than cimetidine $(86 \%$ versus $74 \%$, respectively). Patients with healed ulcers at either week 2 or week 4 had a final endoscopy performed at week 8 . The rate of ulcer recurrence was significantly greater $(\mathrm{P}=0.021)$ in the cimetidine group at week 8 compared with the nizatidine group: $21 \%$ versus $7.3 \%$, respectively. Increasing tolerance to $\mathrm{H}_{2}$ receptor antagonist therapy with prolonged use may explain the higher recurrence rate of cimetidine. Both drugs provided equally rapid and effective symptomatic relief from epigastric pain after two weeks of therapy. Both were equally safe and free from treatment-related adverse effects.

Key Words: Cimetidine, Duodenal ulcer, Nizatidine, Trial

\section{Récurrence de l'ulcère duodénal aigu}

RÉSUMÉ : La nizatidine, à $300 \mathrm{mg}$ une fois par soir, a été comparée à la cimétidine, $800 \mathrm{mg}$ une fois par soir, pour le traitement de 212 adultes non hospitalisés atteints d'ulcère duodénal aigu, dans le cadre d'un essai multicentrique à double insu, randomisé, d'une durée de huit semaines. Les patients ont subi une endoscopie aux semaines 2, 4 et 8, peu importe le degré de guérison de l'ulcère. Aucune différence significative pour ce qui est du taux de guérison de l'ulcère n'a été observée entre les groupes traités aux semaines 2 et 4 , mais à la semaine 8 , la nizatidine s'accompagnait d'un taux de guérison de l'ulcère

Correspondence and reprints: Dr Bob Bailey, 310 Hys Centre, 11010-101 Street, Edmonton, Alberta T5H 4B9

Received for publication October 21, 1992. Accepted May 25, 1993
JizATIDINE IS A NEW $\mathrm{H}_{2}$ RECEPTOR 1 antagonist of the thiazole class that has been effective in treatment of duodenal ulcers (1-3). A single $300 \mathrm{mg}$ bedtime dose has been shown to suppress nocturnal acid secretion as effectively as equivalent amounts administered in divided doses (4-6). Oncedaily administration is not only more convenient, but also improves patient compliance.

Nizatidine differs structurally from other $\mathrm{H}_{2}$ receptor antagonists. Whereas cimetidine contains an imidazole molecular ring and ranitidine contains a furan ring, nizatidine and famotidine each contain a thiazole ring. These molecular differences account for differences between the $\mathrm{H}_{2}$ receptor antagonists in potency and side effects (4).

Cimetidine, administered in an 800 mg bedtime dose, heals duodenal ulcers in approximately $80 \%$ of patients after four weeks of treatment $(5,7,8)$. Cimetidine demonstrated a $72 \%$ reduction in nocturnal acid output. Nizatidine, given in a $300 \mathrm{mg}$ bedtime dose, had an $86 \%$ reduction in nocturnal acid output, but it did not suppress daytime intragastric acidity $(4,9)$.

The objective of the present study 
nettement plus élevé ( $\mathrm{P}=0,036)$ que la cimétidine ( $86 \%$ contre $74 \%$ respectivement). Les patients dont les ulcères avaient guéri, soit à la semaine 2 ou à la semaine 4 , ont eu une endoscopie finale à la semaine 8 . Le taux de récurrence de l'ulcère a été nettement plus grand $(\mathrm{P}=0,021)$ dans le groupe cimétidine à la semaine 8 , en comparaison avec le groupe nizatidine : $21 \%$ contre $7,3 \%$ respectivement. L'augmentation de l'épuisement de l'effet du traitement aux inhibiteurs $\mathrm{H}_{2}$ suite à leur emploi prolongé pourrait expliquer le taux de récurrence plus élevé avec la cimétidine. Les deux médicaments ont offert un soulagement aussi rapide et efficace de la douleur épigastrique après deux semaines de traitement. Les deux se sont révélés aussi sûrs et dépourvus d'effets secondaires liés au traitement.

was to compare efficacy and safety of nizatidine and cimetidine for short term treatment of acute duodenal ulcers. The drugs were administered as a single bedtime dose of either $300 \mathrm{mg}$ of nizatidine or $800 \mathrm{mg}$ of cimetidine. A prospective, randomized, double-blind, parallel group study was performed at five Canadian centres to assess endoscopic healing of ulcers, relief of symptoms, side effects and tolerance after eight weeks of treatment with either study drug.

This Canadian study was part of a larger international clinical trial involving over 500 patients, which has been previously reported (10). A short addendum to that article cited the results from the entire database, which included the complete results from this Canadian portion.

\section{PATIENTS AND METHODS}

Patient population: Male or female out-patients 18 years or older with peptic ulcer disease were eligible for the study. Women were of nonchildbearing potential or had to use an approved method of contraception. All patients had to demonstrate an acute duodenal ulcer between 2.5 and $3.0 \mathrm{~cm}$ in diameter, as diagnosed by endoscopy. All patients gave written informed consent.

Patients were not eligible if they had: previous esophageal or gastric surgery (except for single closure of perforation); pyloric stenosis; ulcer complications (including stenosis, hemorrhage or perforations); gastric, postbulbar, prepyloric, channel or giant antral ulcer; Zollinger-Ellison syndrome; cancer; or clinically relevant cardiovascular, hepatic, renal or respiratory disorders. Other reasons for ex- clusion included concurrent treatment with corticosteroids, nonsteroidal antiinflammatory agents or other ulcerogenic regimens, or use of an $\mathrm{H}_{2}$ receptor antagonist, prostaglandin or sucralfate within three days before enrolment. Pregnant or lactating women were not eligible.

Baseline laboratory values for enrolment included: leukocytes, at least $3000 / \mathrm{mm}^{3}$; hemoglobin, at least $10 \mathrm{~g} / \mathrm{dL}$; blood urea nitrogen, $50 \mathrm{mg} / \mathrm{dL}$ or less; bilirubin, $1.5 \mathrm{mg} / \mathrm{dL}$ or less; and aspartate aminotransferase, $50 \mathrm{IU} / \mathrm{L}$ or less.

Study design: After patients signed an informed consent, a screening endoscopy, electrocardiogram, laboratory tests and complete physical examination were performed within three days of study start. A medical history that recorded tobacco and alcohol consumption, use of antacids, previous therapy and gastrointestinal symptoms was taken at the same time. When appropriate, a pregnancy test was given.

After enrolment, follow-up visits were scheduled at two, four and eight weeks ( \pm three days). Endoscopic examinations were scheduled for week 2 (after two weeks of drug therapy) and week 8 (after eight weeks of therapy). If the patient's ulcer had not healed at week 2, an additional endoscopy was scheduled for week 4. Even if a patient's ulcer healed at week 2 or week 4 , the patient was required to remain in the study until week 8 when the final endoscopy was performed. In the event of a relapse at week 8 , the patient was considered a treatment success. An ulcer was considered completely healed if the mucosa was completely regenerated (epithelialization) and no ulcer crater was visible.
Drug administration: Patients were randomized to one night-time dose of either $300 \mathrm{mg}$ nizatidine or $800 \mathrm{mg}$ cimetidine. All patients received antacid tablets ( $200 \mathrm{mg}$ aluminum hydroxide, $200 \mathrm{mg}$ magnesium hydroxide, 25 mg simethicone) for relief of peptic ulcer symptoms if needed.

Efficacy and safety measurement: To determine effectiveness of the study drugs in relieving symptoms, patients kept a daily diary of severity of daytime and night-time dyspepsia, epigastric pain and heartburn. Severity of ulcer symptoms was measured on a scale from $O$ (no pain) to 4 (terrible pain).

To assess patient compliance, patients brought all bottles of study medication and antacid tablets with them to each clinic visit, and the remaining number of study capsules and antacid tablets were counted and recorded. $\mathrm{Pa}$ tients also returned daily diaries at each clinic visit.

Safety of the study drugs, including adverse events and drug tolerance, were also assessed. Laboratory tests were repeated at each visit and an electrocardiogram was performed at the final visit. Laboratory tests done included complete blood cell count, platelets, complete chemistry profile, alanine aminotransferase and erythrocyte sedimentation rate. Routine urinalysis was also done.

Statistical analysis: Cumulative healing rates were analyzed at two, four and eight weeks of treatment by a linear modelling technique (11). A 95\% confidence interval for treatment differences was computed using the normal approximation to the binomial distribution. Patients whose ulcers were categorized as healed by endoscopy at one visit were considered to be healed at all subsequent visits, unless a later endoscopy revealed a recurrent ulcer. Healing rates were summarized for two categories of patients: the intent-totreat category, which included all patients enrolled; and the efficacy population, all patients who completed the study.

The other efficacy variables, eg, antacid consumption, symptom severity, frequency and overall assessment of well-being, were evaluated by analysis 
TABLE 1

Factors at baseline by treatment

\begin{tabular}{lcc}
\hline Factors & Nizatidine & Cimetidine \\
\hline Male/female & $66(62 \%) / 40(38 \%)$ & $74(70 \%) / 32(30 \%)$ \\
Age (years) & $46 \pm 14$ & $47 \pm 14$ \\
Height $(\mathrm{cm})$ & $168 \pm 10.23$ & $168 \pm 9.99$ \\
Weight $(\mathrm{kg})$ & $69 \pm 13$ & $70 \pm 14$ \\
Smokers/nonsmokers & $55(52 \%) / 51(48 \%)$ & $68(64 \%) / 38(36 \%)$ \\
Alcohol consumers/ & $35(33 \%) / 71(67 \%)$ & $31(29 \%) / 75(71 \%)$ \\
$\quad$ abstainers & & \\
\hline
\end{tabular}

TABLE 3

Ulcer symptoms and associated endoscopic findings at baseline

\begin{tabular}{lcc}
\hline Variable & Nizatidine & Cimetidine \\
\hline Pain & & \\
Day & $1.61 \pm 0.8$ & $1.62 \pm 0.8$ \\
Night & $1.15 \pm 1.0$ & $1.14 \pm 1.0$ \\
Dyspepsia severity & & \\
Day & $1.51 \pm 1.3$ & $1.42 \pm 1.3$ \\
Night & $1.04 \pm 1.4$ & $0.93 \pm 1.4$ \\
Epigastric pain severity & & \\
Day & $2.44 \pm 1.0$ & $2.45 \pm 1.1$ \\
Night & $1.89 \pm 1.6$ & $1.86 \pm 1.5$ \\
Heartburn severity & & \\
Day & $0.87 \pm 1.1$ & $1.00 \pm 1.2$ \\
Night & $0.54 \pm 1.1$ & $0.61 \pm 1.1$ \\
Associated findings: number $(\%)$ & \\
Edema & $46(43)$ & $44(42)$ \\
Scarring & $41(39)$ & $37(35)$ \\
Erosions & $21(20)$ & $22(21)$ \\
Gastritis & $9(8.5)$ & $6(5.7)$ \\
Esophagitis & $4(3.8)$ & $8(7.5)$ \\
Bleeding & $1(0.9)$ & $1(0.9)$ \\
\hline
\end{tabular}

TABLE 2

Clinical factors at baseline by treatment

\begin{tabular}{lcc}
\hline Factors & $\begin{array}{c}\text { Nizatidine } 300 \mathrm{mg} \\
\text { number }(\%)\end{array}$ & $\begin{array}{c}\text { Cimetidine } 800 \mathrm{mg} \\
\text { number }(\%)\end{array}$ \\
\hline $\begin{array}{l}\text { Previous ulcer } \\
\text { Yes }\end{array}$ & $83(78)$ & $88(83)$ \\
No & $23(22)$ & $18(17)$ \\
Previous antacid use & $30(28)$ & $46(43)$ \\
Yes & $76(72)$ & $60(57)$ \\
No & & $70(66)$ \\
Previous cimetidine use & $72(68)$ & $36(34)$ \\
$\quad$ Yes & $34(32)$ & $40(38)$ \\
No & & $66(62)$ \\
Previous ranitidine use & $37(35)$ & $25 \pm 31$ \\
$\quad$ Yes & $69(65)$ & $79 \pm 96$ \\
No & $29 \pm 49$ & \\
Months since & & \\
recent ulcer & $87 \pm 87$ & \\
Months since first & & \\
ulcer & &
\end{tabular}

TABLE 4

Ulcer healing rates by treatment

\begin{tabular}{|c|c|c|c|}
\hline Visit & $\begin{array}{l}\text { Nizatidine } \\
\mathrm{n} / \text { total }(\%)\end{array}$ & $\begin{array}{l}\text { Cimetidine } \\
\text { n/total }(\%)\end{array}$ & $P$ value \\
\hline \multicolumn{4}{|c|}{ Intent-to-treat analysis $(n=212)$} \\
\hline Week 2 & $40 / 106(38)$ & $41 / 106(39)$ & 0.89 \\
\hline Week 4 & $75 / 106(71)$ & $78 / 106(74)$ & 0.65 \\
\hline Week 8 & $85 / 106(80)$ & $73 / 106(69)$ & 0.06 \\
\hline \multicolumn{4}{|c|}{ Efficacy analysis $(n=201)$} \\
\hline Week 2 & $40 / 101(40)$ & $41 / 100(41)$ & 0.84 \\
\hline Week 4 & $75 / 99(76)$ & $78 / 100(78)$ & 0.71 \\
\hline Week 8 & $85 / 99(86)$ & $73 / 99(74)$ & $0.04^{*}$ \\
\hline
\end{tabular}

-Significantly different of variance on ranks (ANOVA) across all visits during the first 14 days and at end-point. All comparisons between nizatidine and cimetidine were twosided.

\section{RESULTS}

Patient characteristics at baseline: A total of 212 patients, ranging in age from 21 to 79 years, were enrolled in the study, with 106 patients in each treatment group. This was one of four clinical trials conducted by each investigator. Patients underwent a screening endoscopy, and based on the pathology were placed in a specific clinical trial. Therefore, data on the number of patients screened for each clinical trial are not available. There were twice as many men as women (140 versus 72 ). No significant differences were found between the two groups at baseline for sex, racial origin, age, height, weight, smoking status and alcohol consumption (Table 1). However, a trend was seen between cigarette smokers in the two groups: $52 \%$ in nizatidine were smokers compared with $64 \%$ in cimetidine.

Approximately $80 \%$ of patients in both groups had a history of ulcers (Table 2). In the nizatidine group, $28 \%$ had used antacids before, compared with $43 \%$ in the cimetidine group $(P=0.022)$. Sixty-eight and $66 \%$ of patients in the nizatidine and cimetidine groups, respectively, had used cimetidine before, whereas between 35 and $38 \%$, respectively, had used ranitidine before. Number of months since the first ulcer and number of months since the most recent ulcer did not differ significantly between groups.

Too few patients had previously used sucralfate, prostaglandins, antacids or other ulcer medications to permit analysis of these variables. For the same reason, it was not possible to compare treatments for the presence at admission of bleeding, esophagitis, hiatal hernia, gastric ulcer, polyps, gastritis or pyloric abnormality.

Patient ratings of daytime and night-time pain, and severity of dyspepsia, epigastric pain and heartburn did not differ significantly between treatment groups (Table 3). None of the other baseline measurements revealed significant differences between treatment groups.

Early withdrawals: Thirteen nizatidine 
TABLE 5

Ulcer healing rates at weeks 2,4 and 8 for sex and smoking status by treatment (intent-to-treat analysis)

\begin{tabular}{|c|c|c|c|}
\hline Variable & $\begin{array}{l}\text { Nizatidine } \\
\text { n/total }(\%)\end{array}$ & $\begin{array}{l}\text { Cimetidine } \\
\mathrm{n} / \text { total }(\%)\end{array}$ & P value \\
\hline \multicolumn{4}{|l|}{ Sex } \\
\hline \multicolumn{4}{|l|}{ Week 2} \\
\hline Male & $25 / 66(38)$ & $25 / 74(34)$ & \multirow{2}{*}{0.27} \\
\hline Female & $15 / 40(38)$ & $16 / 32(50)$ & \\
\hline \multicolumn{4}{|l|}{ Week 4} \\
\hline Male & $46 / 66(70)$ & $51 / 74$ (69) & \multirow{2}{*}{0.15} \\
\hline Female & $29 / 40(73)$ & $27 / 32(84)$ & \\
\hline \multicolumn{4}{|l|}{ Week 8} \\
\hline Male & $51 / 66(77)$ & $47 / 74(64)$ & \multirow{2}{*}{0.054} \\
\hline Female & $34 / 40(85)$ & $26 / 32(81)$ & \\
\hline \multicolumn{4}{|l|}{ Smoking } \\
\hline \multicolumn{4}{|l|}{ Week 2} \\
\hline Smokers & $17 / 57(30)$ & $23 / 68(34)$ & \multirow{2}{*}{$0.03^{\circ}$} \\
\hline Nonsmokers & $23 / 49(47)$ & $18 / 38(47)$ & \\
\hline \multicolumn{4}{|l|}{ Week 4} \\
\hline Smokers & $35 / 57(61)$ & $49 / 68(72)$ & \multirow{2}{*}{0.06} \\
\hline Nonsmokers & $40 / 49(82)$ & $29 / 38(76)$ & \\
\hline \multicolumn{4}{|l|}{ Week 8} \\
\hline Smokers & $44 / 57(77)$ & $43 / 68(63)$ & \multirow{2}{*}{0.08} \\
\hline Nonsmokers & $41 / 49(84)$ & $30 / 38(79)$ & \\
\hline
\end{tabular}

"Significantly different
TABLE 6

Ulcer healing rates for ulcer size and previous ranitidine use by treatment (efficacy analysis)

\begin{tabular}{|c|c|c|c|}
\hline Variable & $\begin{array}{l}\text { Nizatidine } \\
\text { n/total }(\%)\end{array}$ & $\begin{array}{l}\text { Cimetidine } \\
\mathrm{n} / \text { total }(\%)\end{array}$ & P value \\
\hline \multicolumn{4}{|l|}{ Uicer size } \\
\hline \multicolumn{4}{|l|}{ Week 2} \\
\hline$\leq 0.6 \mathrm{~cm}$ & $13 / 29(45)$ & $19 / 26(73)$ & \multirow{2}{*}{$0.001^{\circ}$} \\
\hline$>0.6 \mathrm{~cm}$ & $27 / 72(38)$ & $22 / 74(30)$ & \\
\hline \multicolumn{4}{|l|}{ Week 4} \\
\hline$\leq 0.6 \mathrm{~cm}$ & $25 / 29(86)$ & $23 / 26(89)$ & \multirow[t]{2}{*}{0.04} \\
\hline$>0.6 \mathrm{~cm}$ & $50 / 70(71)$ & $55 / 74(74)$ & \\
\hline \multicolumn{4}{|l|}{ Week 8} \\
\hline$\leq 0.6 \mathrm{~cm}$ & $27 / 29(93)$ & $22 / 25(88)$ & \multirow{2}{*}{0.03} \\
\hline$>0.6 \mathrm{~cm}$ & $58 / 70(83)$ & $51 / 74(69)$ & \\
\hline \multicolumn{4}{|c|}{ Previous ranitidine use } \\
\hline \multicolumn{4}{|l|}{ Week 2} \\
\hline No & $28 / 66(42)$ & $27 / 61$ (44) & \multirow{2}{*}{0.25} \\
\hline Yes & $12 / 35(34)$ & $14 / 39$ (36) & \\
\hline \multicolumn{4}{|l|}{ Week 4} \\
\hline No & $54 / 65(83)$ & $51 / 61(84)$ & \multirow{2}{*}{$0.005^{\circ}$} \\
\hline Yes & $21 / 34(62)$ & $27 / 39$ (69) & \\
\hline \multicolumn{4}{|l|}{ Week 8} \\
\hline No & $58 / 65$ (89) & $48 / 61(79)$ & \multirow{2}{*}{$0.06^{*}$} \\
\hline Yes & $27 / 34(79)$ & $25 / 38(66)$ & \\
\hline
\end{tabular}

"Significantly different patients (12\%) and 12 cimetidine patients $(11 \%)$ did not complete the study. Four cimetidine patients (3.8\%) and one nizatidine patient $(0.9 \%)$ dropped out because of adverse experiences. One patient in each group withdrew because of lack of efficacy. Eight nizatidine patients ( $7.6 \%$ ) withdrew for personal reasons, compared with one cimetidine patient $(0.9 \%)$. Other reasons for withdrawal included lost to follow-up, physician's decision or protocol violations.

Ulcer healing rates: Efficacy variables were analyzed for all 212 patients who entered the study on an intent-to-treat basis and for 201 patients who completed the study, ie, the efficacy population. No significant differences in ulcer healing rates between nizatidine and cimetidine groups were seen at weeks 2 and 4 (Table 4). However, at week 8 in the intent-to-treat analysis, the nizatidine group had a marginal superiority in ulcer healing rates over the cimetidine group ( $80 \%$ versus $69 \%$, $\mathrm{P}=0.06$ ). This trend was reinforced in the efficacy analysis, where superiority of nizatidine over cimetidine in ulcer healing rates at week 8 was significant at $\mathrm{P}=0.036(86 \%$ versus $74 \%$, respectively). At week 8 , significantly more nizatidine-treated patients had healed ulcers. This statistically significant treatment difference was accounted for primarily by a difference in ulcer recurrence rates in nizatidine- and cimetidine-treated patients. It is postulated that the antisecretory effect gradually diminishes and this effect is more significant for cimetidine than nizatidine. Nwokolo et al (12) have noted a significantly decreased antisecretory effect in ranitidine- and cimetidine-treated patients after eight weeks of treatment. These studies have shown that nizatidine has the least loss of antisecretory activity over time. Because the effect is more pronounced after eight weeks of therapy than after two or four, its clinical effect is not seen until eight weeks of treatment.

Ulcer recurrence rates: To evaluate recurrence rates, patients whose ulcers healed at weeks 2 or 4 remained in the study until the final week 8 , and received the same dose of study medication. At that time, they received a final endoscopic examination. Rate of recurrence was significantly greater
$(\mathrm{P}=0.021)$ in the cimetidine group than in the nizatidine group; 15 of $72(21 \%)$ in the former group had endoscopically confirmed ulcer recurrence at week 8 compared with only five of 69 (7.3\%) in the latter group.

Ulcer healing rates were analyzed for different subsets of patients in both intent-to-treat and efficacy populations (Tables 5,6). Several covariates showed differences between groups. Women healed faster than men by week 8 (intent-to-treat, $\mathrm{P}=0.054$; efficacy, $\mathrm{P}=0.049$ ). Smokers had a lower healing rate than nonsmokers at week 2 (intent-to-treat, $\mathrm{P}=0.025$; efficacy, $\mathrm{P}=0.019$ ) and marginally at week 4 (intent-to-treat, $\quad \mathrm{P}=0.056$; efficacy, $\mathrm{P}=0.012$ ) and week 8 (intent-to-treat, $\mathrm{P}=0.082$; efficacy, $\mathrm{P}=0.011$ ). Patients with smaller ulcers $(0.6 \mathrm{~cm}$ or less) healed faster at all weeks than patients with larger ulcers (intent-to-treat, $\mathrm{P}=0.002, \mathrm{P}=0.038, \mathrm{P}=0.045$; efficacy, $\mathrm{P}=0.001, \mathrm{P}=0.035, \mathrm{P}=0.032$ ). Rates of healing were also significantly higher for patients without duodenitis or edema at the ulcer site.

Results of analyses of the efficacy population were similar to the intent- 
to-treat patients, although the magnitude of effect was larger in the former population. Two subsets that were close to being significantly different in the intent-to-treat were statistically significant in the efficacy category. Women had significantly better healing rates than men at week 8 ( $84 \%$ versus $69 \%$, respectively, $\mathrm{P}=0.049$ ), and nonsmokers had significantly higher healing rates than smokers at each week (week 2: $35 \%$ versus $51 \%$, respectively, $\mathrm{P}=0.019$; week $4: 75 \%$ versus $83 \%$, respectively, $\mathrm{P}=0.012$; week $8: 66 \%$ versus $88 \%$, respectively, $\mathrm{P}=0.011$ ).

Ulcer symptoms and antacid consumption: Except for dyspepsia, no significant differences were found between treatments for any pain measurement or number of antacid tablets consumed. However, the nizatidine group experienced dyspepsia more frequently than the cimetidine group when the average of weeks 2 to 4 was analyzed $(\mathrm{P}=0.041)$ and when week 4 was analyzed separately $(\mathrm{P}=0.033)$. Analysis of number of antacid tablets consumed revealed that patients in the cimetidine group consumed more tablets on day 1 than patients in the nizatidine group $(\mathrm{P}=0.051)$, although the difference was not quite significant. When measurements of daytime pain were analyzed, the nizatidine group experienced improvement, although not significant, in daytime epigastric pain at day $1 \mathrm{com}$ pared with the cimetidine group $(P=0.061)$. Similarly, severity of daytime pain, averaged for three symptoms - epigastric pain, dyspepsia and heartburn - was significantly improved for the nizatidine group at day 56 compared with the cimetidine group $(P=0.049)$. Severity of pain on all other days did not differ significantly between the two treatments.

Adverse events: Adverse events were reported whether they were believed to have been caused by treatment with the study drugs. Frequencies of all reported adverse events were comparable between the two treatment groups (Table 7). In addition, abnormalities detected during the endoscopic examination at the final visit were compared with those noted at admission to the study. Of patients with hiatus hernia at admission, significantly fewer in the nizatidine group (none of five) than in the cimetidine group (four of five) had a hiatal hernia at the final visit ( $0 \%$ versus $80 \%$, $\mathrm{P}=0.010$ ), but this result should be regarded with caution because there were only five patients in each group.

Laboratory tests: Significantly more patients in the cimetidine group, versus in the nizatidine group, had abnormally high serum creatinine values $(\mathrm{P}=0.004)$ and high neutrophil counts $(\mathrm{P}=0.031)$. None of the other laboratory values (normal at baseline versus abnormal at follow-up) differed significantly between the two treatments.

\section{DISCUSSION}

In this study, a once-nightly dose of nizatidine $(300 \mathrm{mg}$ ) was as effective as a once-nightly dose of cimetidine ( 800 $\mathrm{mg}$ ) when given for up to four weeks of treatment for acute duodenal ulcers. Nizatidine and cimetidine had comparable ulcer healing rates after two weeks (40\% versus $41 \%$ ) and after four weeks ( $76 \%$ versus $78 \%$ ). However, after eight weeks of therapy, nizatidine had a significantly higher ulcer healing rate than cimetidine ( $86 \%$ versus $74 \%$, $\mathrm{P}=0.036$ ). Between four and eight weeks of therapy, ulcer healing rates in the nizatidine group increased by $10 \%$, whereas in the cimetidine group, ulcer healing rates dropped by $5 \%$.

The most unexpected finding in this study was the lower ulcer healing rate in the cimetidine group at 8 weeks of therapy; this lower healing rate may be due to a difference in design between this study and earlier studies. In previous studies, patients were not endoscoped again at eight weeks of treatment if ulcers had healed at four weeks. As a result, if a patient's ulcer recurred between four and eight weeks of treatment, it was not detected. In the present study, however, patients whose ulcers had healed after two or four weeks of treatment were re-endoscoped at eight weeks. Consequently, a significantly greater $(\mathrm{P}=0.021)$ number of cimetidine patients in our study had a recurrence of ulcers at eight weeks. Only $7.3 \%$ of nizatidine patients had experienced a recurrence of ulcers compared with $21 \%$ of cimetidine patients.
TABLE 7

Adverse events

\begin{tabular}{lcc}
\hline $\begin{array}{l}\text { Adverse } \\
\text { event }\end{array}$ & $\begin{array}{c}\text { Nizatidine } \\
\text { frequency } \\
(\%)\end{array}$ & $\begin{array}{c}\text { Cimetidine } \\
\text { frequency } \\
(\%)\end{array}$ \\
\hline $\begin{array}{l}\text { Flatulence } \\
\text { Diarrhea }\end{array}$ & $5(4.8)$ & $7(6.8)$ \\
Constipation & $3(2.9)$ & $4(3.9)$ \\
Nausea & $2(0.9)$ & $4(3.9)$ \\
Nausea and & $1(0.9)$ & $2(2.0)$ \\
$\quad$ vomiting & & $2(1.9)$ \\
Dizziness & $4(3.8)$ & $2(2.0)$ \\
Insomnia & $3(3.0)$ & $1(1.0)$ \\
Nervousness & $1(1.0)$ & $2(2.0)$ \\
Asthenia & $3(2.9)$ & $6(5.9)$ \\
Headache & $5(4.9)$ & $3(3.1)$ \\
\hline
\end{tabular}

This significant difference between ulcer recurrence rates of nizatidine and cimetidine in our study may be explained by one or more of several possible factors. One might expect that patients whose ulcers had healed after four weeks would tend to reduce drug compliance for the remaining four weeks. However, drug compliance in the two patient treatment groups did not differ between four and eight weeks of treatment. Moreover, there were no notable differences in patient characteristics between treatments. Patients whose ulcers recurred between four and eight weeks of therapy did not differ in any variable from the patient population as whole. In fact, where earlier studies showed that ulcer recurrence rates were higher among smokers than nonsmokers $(2,3,13)$, the present study did not detect any difference in the recurrence rate.

One possible explanation for differences in ulcer recurrence rates in our study may be based upon the desensitization to $\mathrm{H}_{2}$ receptor antagonist use that reportedly occurs over prolonged periods. In a recent article (12), differences were reported in intragastric acidity to various $\mathrm{H}_{2}$ receptor antagonists. The researchers found a progressive return to previous levels of intragastric acidity after 29 days of administration in normal volunteers who received a single nocturnal dose of an $\mathrm{H}_{2}$ receptor antagonist (cimetidine, $\mathrm{ni}$ zatidine or famotidine). However, large 
differences were seen between specific $\mathrm{H}_{2}$ receptor antagonists. Residual nocturnal acidity values by day 29 were $22 \%$ for cimetidine compared with $8 \%$ for nizatidine.

Perhaps antisecretory effects of nizatidine may account for significant differences in recurrence rates between the two $\mathrm{H}_{2}$ receptor antagonists. Because of differences in the molecular structure of cimetidine and nizatidine, nizatidine may be associated with a decreased tendency to develop tolerance. Although desensitization of $\mathrm{H}_{2}$ receptors to prolonged $\mathrm{H}_{2}$ receptor antagonist use is known to occur in patients with Zollinger-Ellison syndrome (14), another report (12) is the first to document this tolerance phenomenon among $\mathrm{H}_{2}$ receptor antagonists used to treat duodenal ulcer in normal volunteers.

\section{REFERENCES}

1. Cloud ML, Offen WW, Matsumoto C, Chernish SM. Healing with recurrence of active duodenal ulcer with nizatidine. Clin Pharmacol Therap 1989;46:310-6.

2. Simon B, Cremer M, Dammann HG, et al. $300 \mathrm{mg}$ nizatidine at night versus $300 \mathrm{mg}$ ranitidine at night in patients with duodenal ulcer: A multicentre trial in Europe. Scand J Gastroenterol 1987;22(Suppl 136):61-70.

3. Dyck WP, Cloud ML, Offen WW, Matsumoto C, Chernish SM.

Treatment of duodenal ulceration in the United States. Scand J Gastroenterol 1987;22(Suppl 136):47-55.

4. Dammann HG, Gottlieb WR, Walter TA, Muller P, Simon B, Keohane P. The 24-hour acid suppression profile of nizatidine. Scand J Gastroenterol 1987;22(Suppl 136):56-60.

5. Capurso I, Dal Monte PR, Mazzeo F, et al. Cimetidine, $800 \mathrm{mg}$ at night
In the present study, both nizatidine and cimetidine were equally effective in providing rapid symptomatic relief from epigastric pain. Most patients were free from pain after two weeks of treatment with either drug, although patients on nizatidine experienced dyspepsia more often than patients on cimetidine. Antacid consumption among the two treatment groups also decreased dramatically after two weeks of treatment, further evidence of the prompt symptomatic effectiveness of nizatidine and cimetidine.

Both drugs were equally safe and free from treatment-related adverse effects. Frequency of abnormal laboratory values did not differ significantly between the two treatment groups, except for abnormally high serum creatinine values and neutrophil counts among patients on cimetidine. These abnormali-

versus $400 \mathrm{mg}$ twice daily, in the treatment of duodenal ulcer. Scand J Gastroenterol 1986;21:6-10.

6. De Gara CJ, Gledhill T, Hunt RH. Nocturnal gastric acid secretion: Its importance in the pathophysiology and rational therapy of duodenal ulcer. Scand J Gastroenterol 1986;21:17-24.

7. Dickson B. Cimetidine, $800 \mathrm{mg}$ once daily: Preliminary European clinical data evaluation. Scand J Gastroenterol 1986;21:11-24.

8. Kildebo S, Aronsen O, Benersen B, et al. Cimetidine $800 \mathrm{mg}$ at night in the treatment of duodenal ulcers. Scand J Gastroenterol 1985;20:1147-50.

9. Lanzon-Miller S, Pounder RE, Chronos NAF, Raymond F, Hamilton MR, Dalgleish D. Twenty four hour intragastric acidity and plasma gastrin concentration in healthy volunteers taking nizatidine $150 \mathrm{mg}$, nizatidine $300 \mathrm{mg}$, ranitidine $300 \mathrm{mg}$, or placebo at 2100 h. Gut $1988 ; 29: 1364-9$. ties were not clinically significant, however.

\section{CONCLUSIONS}

A single nocturnal dose of nizatidine (300 mg) is as effective and safe as a single nocturnal dose of cimetidine (800 mg) for healing duodenal ulcers and relieving symptomatic pain. Although more patients have completely healed ulcers after four weeks, some patients may experience a recurrence of ulcers by eight weeks. Tolerance to $\mathrm{H}_{2}$ receptor antagonists may develop with continued administration; however, nizatidine is associated with a reduced ulcer recurrence rate at eight weeks of treatment. Therefore, for use beyond four weeks, nizatidine may be more effective than cimetidine. Additional long term studies will be needed to confirm the results of the present study.

10. Cherner JA, Loud ML, Offen WW, et al. Comparison of nizatidine and cimetidine as once-nightly treatment of acute duodenal ulcer. Am J Gastroenterol 1980;84:769-74.

11. Grizzle JE, Starmer CF, Koch GG. Analysis of categorical data by linear models. Biometrics 1969;25:489-504.

12. Nwokolo CU, Smith JTL, Gavey C, Sawyer A, Pounder RE. Tolerance during 29 days of conventional dosing with cimetidine or ranitidine. Aliment Pharmacol Therap 1990;4(Suppl 1):29-45

13. Korman MG, Shaw RG, Hansky J, et al. Influence of smoking on healing rate of duodenal ulcer in response to cimetidine or high dose antacid. Gastroenterology 1981;80:1451-3.

14. Allende HD, Bissonette BM, Raufman $\mathrm{JP}$, et al. Progressive increase in drug requirement in the long-term medical management of patients with Zollinger-Ellison syndrome. Gastroenterology 1982;82:1007. 


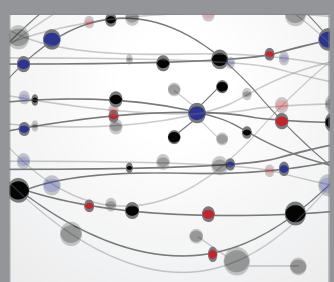

The Scientific World Journal
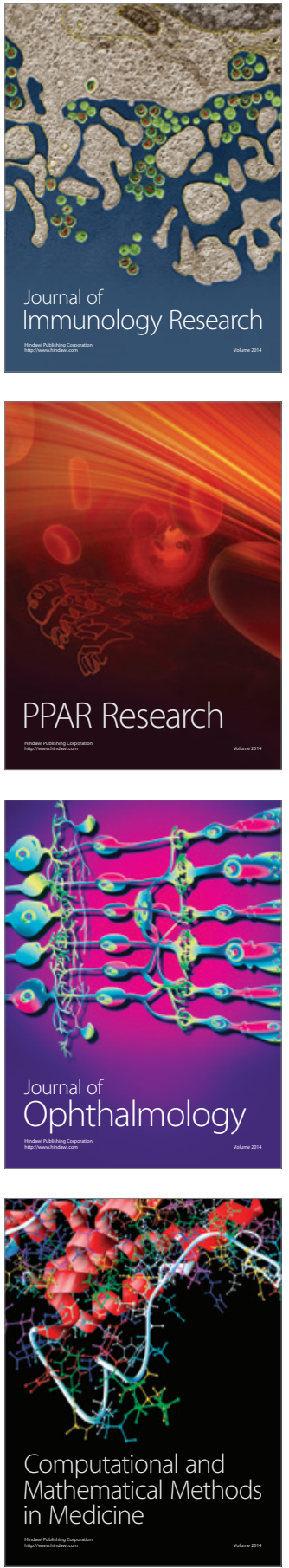

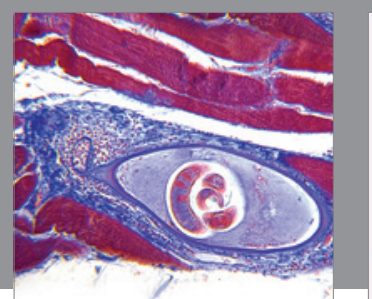

Gastroenterology Research and Practice

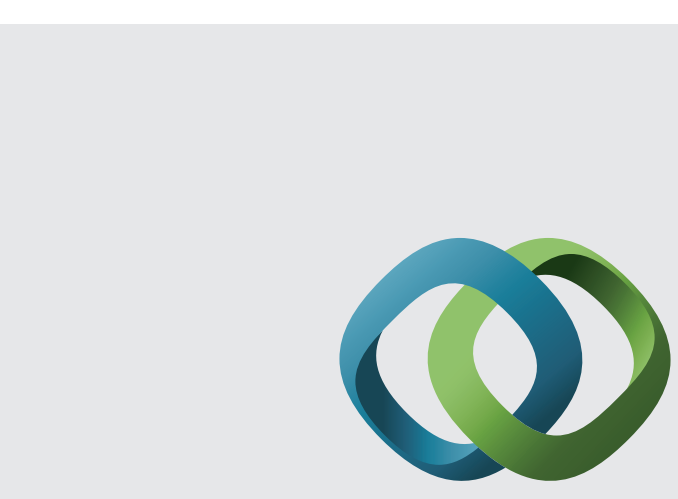

\section{Hindawi}

Submit your manuscripts at

http://www.hindawi.com
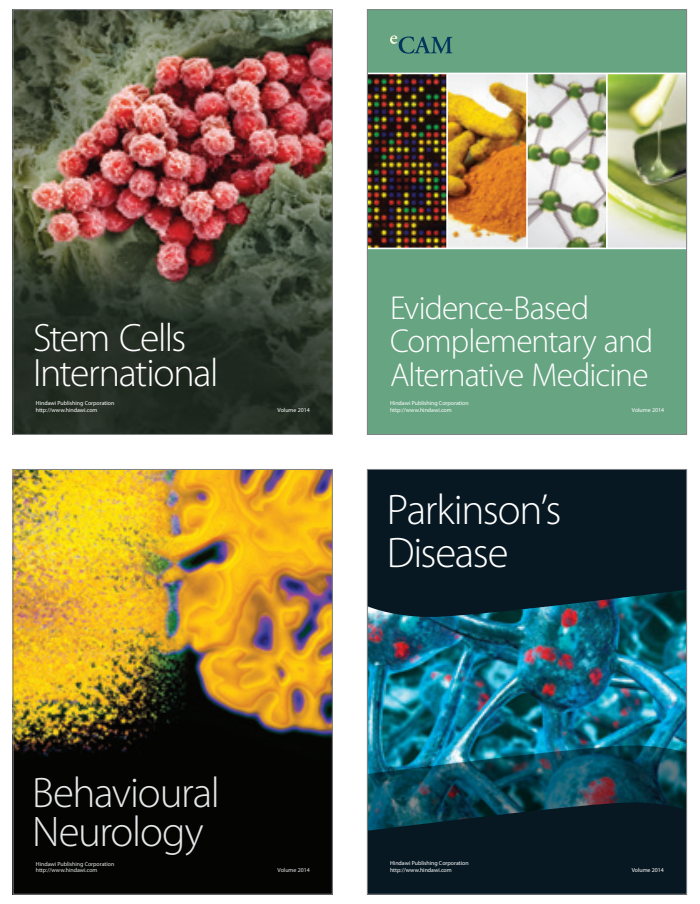
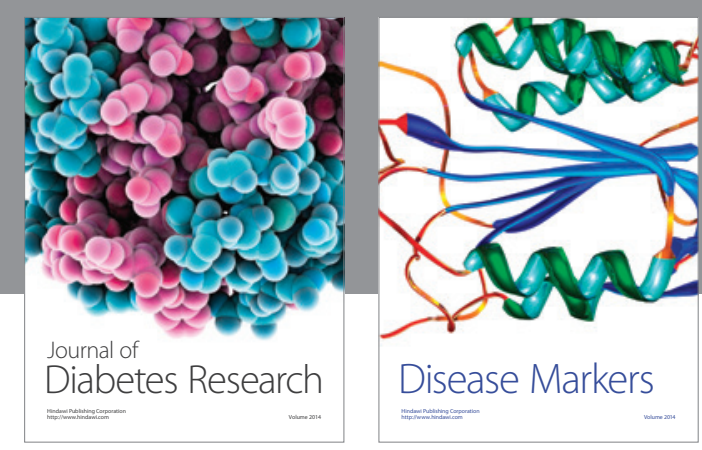

Disease Markers
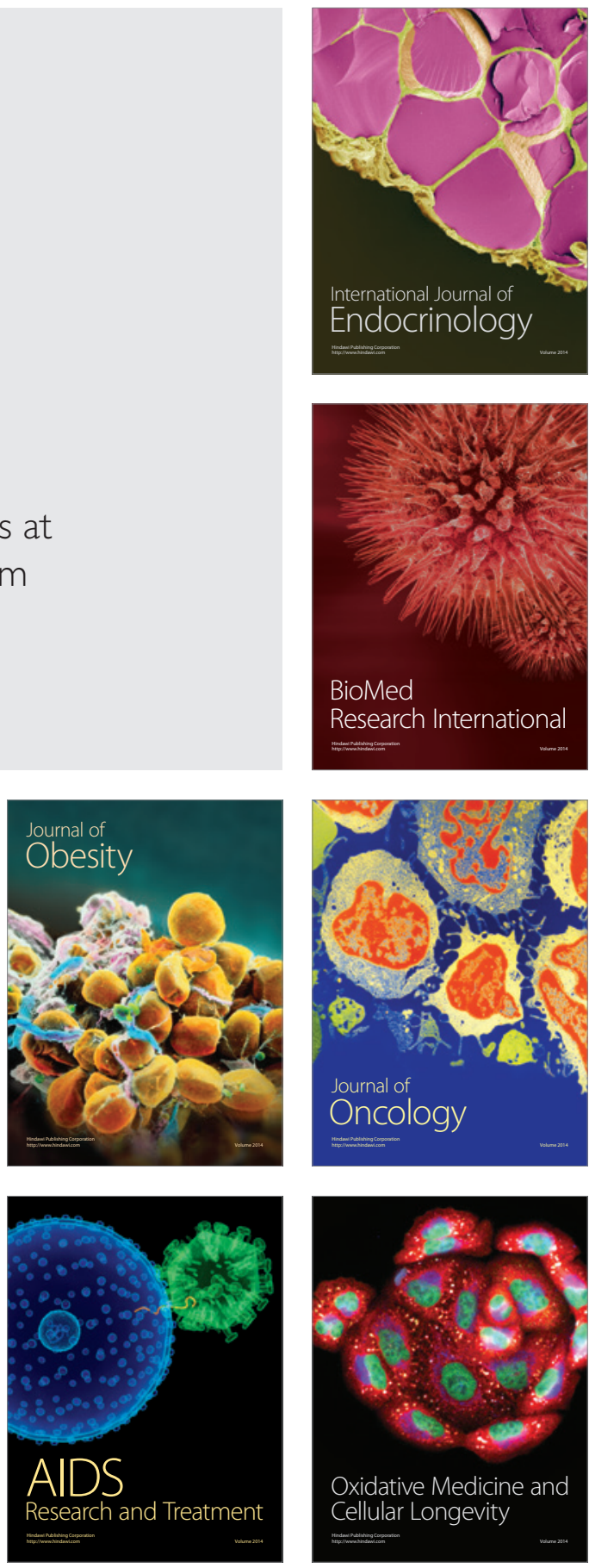